\title{
Analisis penggunaan aplikasi whatsapp terhadap pembelajaran daring (studi kasus mahasiswa pendidikan biologi FKIP UM parepare)
}

\author{
Nurul Latifah Thahira,1, Patahuddina,2, Jusmiati Jafara,3, Amria,4,* \\ ${ }^{a}$ Program Studi Pendidikan Biologi, Fakultas Kependidikan dan IImu Pendidikan, Universitas Muhammadiyah Parepare, Indonesia. \\ 4 amribyronk@gmail.com \\ * Corresponding Author
}

Received 6 Maret 2021; accepted 10 Maret 2021; published 31 Maret 2021

\section{ABSTRAK}

Penelitian ini bertujuan untuk mengetahui hubungan antara penggunaan aplikasi WhatsApp pada pembelajaran online mahasiswa pendidikan biologi angkatan 2017 FKIP UM Parepare. Jenis penelitian yang digunakan adalah penelitian expost facto dengan menggunakan pendekatan kuantitatif. Penelitian ini dilaksanakan pada bulan Juli-September 2020. Sampel penelitian adalah seluruh mahasiswa Prodi Pendidikan Biologi angkatan 2017 yang masih aktif. Instrumen yang digunakan dalam penelitian ini adalah lembar angket dan dokumentasi. Analisis data menggunakan statistik deskriptif dan analisis statistik inferensial. Dari hasil penelitian ditemukan bahwa kategorisasi penggunaan aplikasi WhatsApp dan pembelajaran online mata pelajaran Biologi angkatan 2017 berada pada kategori sangat tinggi. Ada hubungan yang kuat (nilai sig $(p) 0,000$ ) penggunaan aplikasi WhatsApp terhadap pembelajaran online mahasiswa Pendidikan Biologi angkatan 2017 FKIP UM Parepare.

\section{Analysis of the use of the whatsapp application on online UM parepare)}

This study aims to determine the relationship between the use of the WhatsApp application on online learning of biology education students class 2017 FKIP UM Parepare. The type of research used is ex-post facto research using a quantitative approach. This research was conducted in July-September 2020. The research sample was all students of the 2017 batch of biology education study program who are still active. The instruments used in this study were questionnaire sheets and documentation. Data analysis used descriptive statistics and inferential statistical analysis. From the research results, it was found that the categorization of the use of the WhatsApp application and online learning of biology education students class of 2017 was in the very high category. There is a strong relationship (sig (p) value of 0,000$)$ the use of the WhatsApp application to online learning of biology education students class 2017 FKIP UM Parepare.
KATAKUNCl

Aplikasi Whatsapp, biologi, Pembelajaran Daring

KEYWORDS

Whattsapp,

biology,

Application,

Online Learning

This is an openaccess article under the $\underline{\text { CC-BY-SA }}$ license

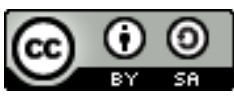

\section{Pendahuluan}

Belajar merupakan suatu kegiatan baik dengan bimbingan tenaga pengajar maupun dengan usahanya sendiri. Kehadiran tenaga pendidik dalam kegiatan belajar dimaksudkan agar belajar lebih lancar, lebih mudah, lebih menyenangkan, dan lebih berhasil. Selanjutnya bagi peserta didik, belajar pada dasarnya untuk memperoleh pengetahuan, keterampilan, dan sikap di mana saja, kapan saja, dan dengan apa saja, sebab sumber belajar terdapat di mana saja dan ada bermacam beragam jenisnya. Salah satu aplikasi yang dapat digunakan melalui sosial media dengan menggunakan aplikasi whatsapp (Handarini \& Wulandari, 2020; So, 2016). 
Pembelajaran daring adalah pembelajaran yang bisa diakses kapan saja dan dimana saja atau tidak dilakukan dalam suatu ruangan kelas (Andrianto Pangondian, Insap Santosa, \& Nugroho, 2019). Pembelajaran daring didefinisikan sebagai upaya menghubungkan pembelajar (siswa) dengan sumber belajarnya (database, pakar/instruktur, perpustakaan) yang secara fisik terpisah atau bahkan berjauhan namun dapat saling berkomunikasi, berinteraksi atau berkolaborasi secara (secara langsung/synchronous dan secara tidak langsung/asynchronous). Pembelajaran daring sangat potensial karena peserta didik maupun pendidik dapat melakukan pembelajaran secara online menggunakan internet (Kuntarto, 2017) dan hal ini direkomendasikan untuk dipakai di era revolusi industri 4.0 (Andrianto Pangondian et al., 2019).

Pembelajaran daring bukan hanya berkutat dengan internet, melainkan aspek penting yaitu "lebih aman (safer)". Kita mengenal learning management systems (LMS) sebagai komponen penting $e$ learning. Pembelajaran daring memperluas komunitas pembelajaran. Memperluas di sini karena antara satu siswa dengan siswa lainnya memiliki akses komunikasi yang lebih baik dibanding diskusi tatap muka yang terbatas oleh ruang dan waktu. Bahkan diskusi tatap muka yang sudah baik pun masih memiliki kendala, dimana ada kecenderungan siswa yang kurang peduli terhadap apa yang dikatakan oleh rekannya (A.N, Bayu, \& S, 2019). Ada banyak media yang digunakan untuk belajar daring. Berbagai platform sudah lama menyediakan jasa ini. Sebut saja misalnya Google Clasroom, Rumah Belajar, Edmodo, Ruang Guru, Zenius, Google Suite for Education, Microsoft Office 365 for Education, Sekolahmu, Kelas Pintar. Inilah yang disebut sebagai platform microbloging (Basori, 2013).

Era pandemi Covid-19, penggunaan aplikasi whatsapp sangat efektif digunakan sebagai sumber belajar, mengingat diharuskannya melakukan kegiatan pembelajaran di rumah. Sehingga para pendidik atau dosen dituntut mendesain pembelajaran dengan memanfaatkan media daring (online) Hal ini sesuai dengan kebijakan tentang pelaksanaan kebijakan pendidikan pada masa darurat penyebaran Corona Virus Disease (Covid-19).Whatsapp memberikan berbagai macam fitur bagi penggunanya dengan mengratiskan pengiriman pesan dan melakukan panggilan secara sederhana, aman, cepat ke berbagai jenis telepon di seluruh penjuru dunia. Pada awalnya, Whatsapp diluncurkan sebagai alternatif SMS. Namun, saat ini aplikasi media sosial whatsapp dapat digunakan untuk mengirim dan menerima berbagai macam media dalam bentuk teks, foto, video, dokumen, dan lokasi, bahkan whatsapp saat ini dapat digunakan untuk melakukan panggilan suara dan panggilan video (Pranajaya \& Wicaksono, 2018).

Berdasarkan hasil observasi yang dilakukan peneliti terhadap mahasiswa Program Studi Pendidikan Biologi Universitas Muhammadiyah Parepare bahwa selama masa pandemi Covid-19 proses perkuliahan menggunakan beberapa aplikasi seperti zoom, google classroom, edmodo, quizizz, brainly dan whatsapp, tetapi beberapa mata kuliah biologi yaitu nutrisi tumbuhan, ekologi hewan, ekologi tumbuhan, mikologi memilih pembelajaran daring (online) melalui aplikasi whatsapp. Hal ini seharusnya berdampak baik, karena melalui aplikasi whatsapp setiap mahasiswa dapat mengakses informasi kapan saja dan dimana saja, sarana positif ini harus dimanfaatkan sebaik-baiknya terutama di era pandemi Covid-19.

Aplikasi whatsapp dalam dunia pendidikan termasuk ke dalam teknologi pendidikan yang dapat difungsikan sebagai alat atau media komunikasi dalam pengelolaan pendidikan dan pengembangan pendidikan. Fitur Chat Group misalnya dapat digunakan oleh dosen dan mahasiswa untuk melakukan komunikasi maupun diskusi pembelajaran melalui media sosial yang terkait dengan kegiatan belajar. Selain itu, fitur pengiriman dokumen pada aplikasi whatsapp juga dapat dimanfaatkan untuk mempermudah mahasiswa dalam mengirimkan tugas maupun media pembelajaran dalam bentuk power point maupun dokumen sehingga proses pembelajaran menjadi lebih maksimal (Abdulhak \& Deni, 2015). 
Aktivitas komunikasi menggunakan WhatsApp dapat dikategorikan ke dalam teori $C M C$ karena whatsapp merupakan salah satu aplikasi pada smartphone yang digunakan sebagai media. Computer Mediated Communication (CMC) adalah istilah yang digunakan untuk melakukan komunikasi antar dua orang atau lebih yang dapat saling berinteraksi melalui komputer. Hal ini menujukkan bahwa pembelajaran jarak jauh sangat berganting pada dukungan perangkat mobile untuk mengakses informasi yang tidak terbatas ruang dan waktu (Gikas \& Grant, 2013).

Pemanfaatan aplikasi whatsapp sebagai sarana belajar disebabkan oleh beberapa hal, diantaranya: sebuah aplikasi yang paling familiar dikalangan umum termasuk dosen, mudah dan praktis dalam pengoperasiannya sehingga untuk menyampaikan pesan yang sederhana sudah dirasa cukup dan hal ini sesuai penelitian bahwa penggunaan whatsapp berguna dalam pembelajaran daring (So, 2016). Faktor akses jaringan internet dibeberapa wilayah kurang baik sehingga aplikasi whatsapp cukup sebagai solusi. Faktor biaya, dengan mengggunakan aplikasi whatsapp biaya kuota relatif lebih murah jika dibanding dengan aplikasi teleconferen, sehingga dosen dan mahasiswa akan memilih yang lebih ekonomis (Pranajaya \& Wicaksono, 2018).

Tujuan dalam penelitian ini adalah untuk mengetahui hubungan penggunaan aplikasi whatsapp terhadap pembelajaran daring mahasiswa pendidikan biologi angkatan 2017 FKIP UM Parepare. Penelitian ini diharapkan bermanfaat bagi mahasiswa yaitu menjadi masukan dalam memanfaatkan aplikasi whatsapp sebagai bagian dari media pembelajaran, selain itu, bagi dosen juga dapat menjadi referensi untuk meningkatkan kualitas pembelajaran melalui penggunaan aplikasi whatsapp. Penelitian ini juga diharapkan membawa manfaat bagi peneliti yaitu memperoleh pengalaman dalam penggunaan aplikasi whatsapp terhadap pembelajaran daring. Berdasarkan uraian latar belakang, peneliti bermaksud melakukan penelitian dengan judul Analisis Penggunaan Aplikasi Whatsapp terhadap Pembelajaran Daring (Studi Kasus Mahasiswa Pendidikan Biologi FKIP UM Parepare).

\section{Metode}

Jenis penelitian yang digunakan adalah penelitian ex-post facto dengan menggunakan pendekatan kuantitatif, Penelitian ini dilaksanakan di Program Studi Pendidikan Biologi FKIP Universitas Muhammadiyah Parepare Kampus II Jalan Jendral Ahmad Yani Km. 6 Kecamatan Soreang Kota Parepare pada bulan Juli-September 2020. Populasi dalam penelitian ini adalah seluruh mahasiswa Program Studi Pendidikan Biologi UM Parepare, sedangkan sampel penelitian adalah seluruh mahasiswa program studi pendidikan biologi angkatan 2017 yang masih aktif dalam perkuliahan dan menggunakan aplikasi whatsapp dengan total mahasiswa 24 orang. Prosedur dalam penelitian ini dibagi menjadi tiga tahap, yaitu: 1) tahap persiapan, 2) tahap pelaksanaan dan 3) tahap akhir.

Instrumen yang digunakan dalam penelitian ini yaitu lembar angket dan dokumentasi. Lembar angket digunakan untuk mengumpulkan data penggunaan aplikasi whatsapp dan pembelajaran daring. Skala pengukuran penggunaan aplikasi whatsapp dan pembelajaran daring menggunakan skala likert dengan empat bagian skala, yaitu: sangat setuju, setuju, tidak setuju, dan sangat tidak setuju. Pembagian lembar angket dilakukan dengan memanfaatkan aplikasi Google Forms, dimana sampel penelitian dapat memberikan tanggapan terhadap angket secara cepat dimanapun berada dengan menggunakan laptop maupun smartphone yang telah terhubung dengan jaringan internet. Kisi-kisi angket penggunaan aplikasi whatsapp disusun berdasarkan indikator tentang karakteristik, pemanfaatan aplikasi, dan penggunaan aplikasi yang tersebar kedalam gradasi positif dan negatif sedangkan kisi-kisi angket pembelajaran daring disusun berdasarkan indikator perhatian, ketertarikan, minat belajar, keaktifan, kepercayaan diri yang tersebar ke dalam gradasi positif dan negatif.

Sumber data dalam penelitian ini diantaranya: 1) data primer, sumber data primer adalah mahasiswa program studi pendidikan biologi angkatan 2017 berjumlah 24 orang dan data yang didapatkan berupa data penggunaan aplikasi whatsapp dan pembelajaran daring, 2) data sekunder, sumber data sekunder yang digunakan adalah dosen, pimpinan dan seluruh staf di Program Studi 
Pendidikan Biologi UM Parepare. Teknik analisis data menggunakan statistik deskriptif dan analisis statistik inferensial.

\section{Hasil dan Pembahasan}

Hasil analisis deskriptif data angket penggunaan aplikasi whatsapp dengan menggunakan Google Forms kepada mahasiswa pendidikan biologi angkatan 2017 yang diisi oleh 24 mahasiswa, diperoleh mean sebesar 61,29, Skor minimum 41 dan skor maximum 74 dengan skor ideal 100. Selanjutnya distribusi frekuensi dan persentase penggunaan aplikasi whatsapp menunjukkan bahwa terdapat 14 orang mahasiswa berada pada kategori sangat tinggi dengan persentase 58,33\%, 10 orang mahasiswa berada pada kategori tinggi dengan persentase $41,67 \%$, tidak terdapat mahasiswa pada kategori sedang, rendah dan rendah sekali sehingga dapat disimpulkan berdasarkan nilai persentase bahwa penggunaan aplikasi whatsapp mahasiswa pendidikan biologi angkatan 2017 UM Parepare berada pada kategori sangat tinggi.

Pada data angket pembelajaran daring dengan menggunakan Google Forms kepada mahasiswa pendidikan biologi angkatan 2017 yang diisi oleh 24 mahasiswa, diperoleh mean sebesar 65,33 Skor minimum 56 dan skor maximum 76 dengan skor ideal 100. Selanjutnya distribusi frekuensi dan persentase pembelajaran daring menunjukkan bahwa terdapat 21 orang mahasiswa berada pada kategori sangat tinggi dengan persentase $87,5 \%, 3$ orang mahasiswa berada pada kategori tinggi dengan persentase $12,5 \%$, tidak terdapat mahasiswa pada kategori sedang, rendah dan rendah sekali sehingga dapat disimpulkan berdasarkan nilai persentase bahwa pembelajaran daring mahasiswa pendidikan biologi angkatan 2017 UM Parepare berada pada kategori sangat tinggi.

Hasil diatas sejalan dengan penelitian lain yang menunjukkan rata-rata skor 2,78 dengan persentase $69,50 \%$ termasuk kategori sangat setuju siswa menyetujui pembelajaran daringsaat pembelajaran IPA. Pada aspek tersebut dapat diketahui bahwa pembelajaran IPA dengan menggunakan metode pembelajaran daringdapat menumbuhkan semangat dan pemahaman siswa terkait materi yang disampaikan (A.N et al., 2019).

Sesungguhnya pembelajaran daring membutuhkan effort yang besar dari guru dan orang tua, tidak sesederhana yang banyak terjadi. Bagaimana tidak, guru dan orang tua dituntut menciptakan lingkungan belajar yang integratif dan memenuhi berbagai komponen esensial pembelajaran yakni diskursif, adaptif, interaktif dan reflektif (Oktavian \& Aldya, 2020).

Penggunaan WhatAapp untuk forum diskusi serta pendistribusian materi pembelajaran pada mahasiswa, bisa dilaksanakan, cara yang bisa dilakukan yaitu membentuk WhatsApp Grup. WhatsApp group ini akan dengan spontan langsung terlihat apabila ada yang mengirimkan suatu pesan serta aktivitas lain, dimana dapat secara mudah, melontarkan tanggapan yang sesuai berhubungan dengan topic yang diminta untuk didiskusikan. Tujuan yang ingin dicapai antara peserta didik dan pendidik dapat melaksanakan forum berdiskusi serta tersebarnya bahan pembelajaran dengan tidak diharuskan bertemu muka langsung tetapi bisa dilaksanakan dengan daring. Dengan terbentuknya group WhatsApp membuktikan bahwa menyebarkan materi pembelajaran tidak hanya menggunakan blog saja (Prajana, 2017).

Hasil analisis data penggunaan aplikasi whatsapp dengan menggunakan Kolmogorov-Smirnov Normality Test diperoleh nilai peluang sig. 0,200> $\alpha(\alpha=0.05)$ dan Shapiro-Wilk Test diperoleh nilai peluang sig. 0,095> $\alpha(\alpha=0.05)$. Hasil analisis data pembelajaran daring dengan menggunakan Kolmogorov-Smirnov Normality Test diperoleh nilai peluang sig. 0,200> $\alpha(\alpha=0.05)$ dan Shapiro-Wilk Test diperoleh nilai peluang sig. 0,884> $\alpha(\alpha=0.05)$. Jadi, dapat disimpulkan bahwa data penggunaan aplikasi whatsapp dan pembelajaran daring melalui pengujian normalitas dikatakan berdistribusi normal.

Berdasarkan hasil analisis data dengan uji linearitas melalui bantuan SPSS Version 22 terlihat pada tabel ANOVA menunjukkan bahwa nilai sig ( $p$ ) sebesar 0,817 lebih besar dari pada taraf signifikansi $\alpha=0,05(0,817>0,05)$. Jadi dapat disimpukan bahwa hubungan antara penggunaan aplikasi whatsapp dengan pembelajaran daring adalah linier. Selanjutnya pengujian hipotesis penelitian 
menggunakan rumus regresi linier sederhana didapatkan nilai sig $(p)$ sebesar 0,000 . Nilai tersebut lebih kecil dari pada taraf signifikansi $\alpha=0,05(0,000<0,05)$, seperti Tabel 1 berikut.

Tabel 1. Regresi Linier Sederhana

\begin{tabular}{|c|c|c|c|c|c|c|c|}
\hline \multicolumn{8}{|c|}{ Coefficients $^{a}$} \\
\hline \multirow[t]{2}{*}{ Model } & & \multicolumn{2}{|c|}{ Unstandardized Coefficients } & \multirow{2}{*}{$\begin{array}{c}\begin{array}{c}\text { Standardized } \\
\text { Coefficients }\end{array} \\
\text { Beta }\end{array}$} & & \multirow[t]{2}{*}{$t$} & \multirow[t]{2}{*}{ Sig. } \\
\hline & & $\boldsymbol{B}$ & Std. Error & & & & \\
\hline \multirow{2}{*}{1} & $($ Constant $)$ & 29,378 & 5,015 & & & 5,858 & 000 \\
\hline & Aplikasi Whatsapp & 587 & ,081 & & 838 & 7,209 & 000 \\
\hline
\end{tabular}

Berdasarkan Tabel 1, dapat disimpulkan bahwa hipotesis $H_{0}$ ditolak dan hipotesis $H_{1}$ diterima, sehingga ada hubungan yang kuat penggunaan aplikasi whatsapp terhadap pembelajaran daring mahasiswa pendidikan biologi angkatan 2017 FKIP UM Parepare.

Adanya hubungan penggunaan aplikasi whatsapp terhadap pembelajaran daring. Hal ini antara lain disebabkan proses pembelajaran daring sudah memenuhi komponen-komponen dalam pembelajaran daring, diantaranya terdapat pembelajar (mahasiswa), dengan sumber belajarnya (dosen) yang secara fisik terpisah atau bahkan berjauhan namun dapat berkomunikasi, saling berinteraksi, memanfaatkan teknologi seperti internet.

Penelitian yang sama dilakukan Pangestika (2018) menyatakan bahwa pemanfaatan media sosial whatsapp memiliki pengaruh sebesar $83,3 \%$ terhadap penyebaran informasi pembelajaran. Demikian pula penelitian lain menyatakan pengaruh dari pemanfaatan media sosial whatsapp terhadap motivasi belajar Bahasa Indonesia siswa sebesar 74,8\%, sedangkan $25,2 \%$ ditentukan oleh faktor lainnya, seperti: faktor lingkungan belajar, faktor keluarga, faktor kecerdasan siswa, serta beberapa faktor lain baik dari dalam diri siswa maupun dari luar (Kamila, 2019). Selama belajar dalam pembelajaran daring (dalam jaringan), siswa/ mahasiswa menerima materi dan berinteraksi dengan teman sejawat dan juga guru/ dosen serta menyelesaikan tugas. Hal ini seharusnya diarahkan ke "berbasis peserta didik" yang aktif sehingga kreativitas peserta didik lebih terasah dan mengecilkan dampak negatif dari pembelajaran online (Kuo, Walker, Schroder, \& Belland, 2014).

Maraknya wabah Covid 19 atau virus corona memaksa berbagai aspek untuk berbenah kembali. Aspek pendidikan terutama yang terkena dampak dari situasi ini. Pembelajaran yang dulunya berlangsung dengan bertatap muka, kini beralih ke daring. Pembelajaran yang terjadi di perguruan tinggi merupakan salah satu obyek yang bertumbuh subur dalam penggunaan aplikasi WhatsApp Messenger ini selain fungsi Whatsapp yang lain yang menjadi satu di antara media sosial sekarang menjamur dan menggunakannya demi kepentingan bersosialisasi ataupun guna mengirimkan pesan baik dilakukan perseorangan maupun grup (Trisnani, 2017). Aplikasi yang banyak digandrungi menggunakan aplikasi WhatsApp Messenger yaitu pembicaraan/diskusi secara berkelompok (Jumiatmoko, 2016). Jika ditelisik kembali, pembelajaran daring menggunakan aplikasi WhatsApp juga sudah digunakan dengan pendekatan model pembelajaran kolaborative namun masih dikombinasi dengan pembelajaran tatap muka (Prajana, 2017).

Pembelajaran daring dengan menggunakan aplikasi online mampu meningkatkan kemandirian belajar (Oknisih, Wahyuningsih, \& Suryoto, 2019). Dengan meningkatnya sikap kemandirian mahasiswa dalam belajar akan membuat mereka bertanggung jawab akan tugas yang telah diberikan, serta mampu menumbuhkan minat belajar mahasiswa dengan ketersediaan fitur-fitur serta tampilan yang menarik yang disediakan oleh aplikasi.

Keberadaan WhatsApp memudahkan kegiatan komunikasi baik jarak dekat maupun jarak jauh dan merupakan alat komunikasi lisan maupun tulisan, mampu menyimpan pesan dan sangat praktis (Suryadi, Ginanjar, \& Priyatna, 2018). Dalam pemanfaatan WhatsApp pengguna dapat melakukan obrolan online, bertukar foto, berbagi file dan lain-lain, serta kehadiran berbagai fitur menarik dengan kelebihannya yang menarik pengguna (Afnibar \& Fajhriani, 2020). 


\section{Kesimpulan}

Berdasarkan hasil penelitian disimpulkan bahwa: 1) Kategorisasi penggunaan aplikasi whatsapp dan pembelajaran daring mahasiswa pendidikan biologi angkatan 2017 UM Parepare berada pada kategori sangat tinggi. 2) Ada hubungan yang kuat penggunaan aplikasi whatsapp terhadap pembelajaran daring mahasiswa pendidikan biologi angkatan 2017 FKIP UM Parepare. Hal ini dibuktikan dari hasil analisis regresi linier sederhana dimana didapatkan nilai sig $(p)$ sebesar 0,000 lebih kecil dari pada taraf signifikansi $\alpha=0,05(0,000<0,05)$.

\section{Ucapan Terimakasih}

Terima kasih kepada para teman sejawat yang dengan sabar memberikan arahan dan masukan terhadap penulis, seluruh mahasiswa Program Studi Pendidikan Biologi angkatan 2017 yang telah meluangkan waktunya dan pihak Program Studi Pendidikan Biologi FKIP UM Parepare yang telah memberikan izin melakukan penelitian.

\section{Referensi}

A.N, S., Bayu, R., \& S, M. (2019). Persepsi Siswa Dalam Studi Pengaruh Daring Learning Terhadap Minat Belajar Ipa. SCAFFOLDING: Jurnal Pendidikan Islam Dan Multikulturalisme, 1(2), 30 38. https://doi.org/10.37680/scaffolding.v1i2.117

Abdulhak, I., \& Deni, D. (2015). Teknologi Pendidikan. Bandung: PT Remaja Rosdakarya.

Afnibar, A., \& Fajhriani, D. N. (2020). Pemanfaatan WhatsAPP sebagai Media Komunikasi Kegiatan Belajar ( Studi terhadap Mahasiswa UIN Imam Bonjol Padang ). Al-Munir: Jurnal Komunikasi Dan Penyiaran Islam, 11(1), 70-83. Retrieved from https://ejournal.uinib.ac.id/jurnal/index.php/almunir/article/download/1501/1122

Andrianto Pangondian, R., Insap Santosa, P., \& Nugroho, E. (2019). Faktor - Faktor Yang Mempengaruhi Kesuksesan Pembelajaran Daring Dalam Revolusi Industri 4.0. In Sainteks 2019 (pp. 56-60). Retrieved from https://seminar-id.com/semnas-sainteks2019.html

Basori, B. (2013). Pemanfaatan Social Learning Network "Edmodo" Dalam Membantu Perkuliahan Teori Bodi Otomotif Di Prodi Ptm Jptk Fkip Uns. Jurnal Ilmiah Pendidikan Teknik Dan Kejuruan, 6(2). https://doi.org/10.20961/jiptek.v6i2.12562

Gikas, J., \& Grant, M. M. (2013). Mobile computing devices in higher education: Student perspectives on learning with cellphones, smartphones \& social media. Internet and Higher Education, 19, 18-26. https://doi.org/10.1016/j.iheduc.2013.06.002

Handarini, O. I., \& Wulandari, S. S. (2020). Pembelajaran Daring Sebagai Upaya Study From Home (SFH) Selama Pandemi Covid 19. Jurnal Pendidikan Administrasi Perkantoran (JPAP), 8(3), 496-503.

Jumiatmoko, M. (2016). Whatsapp Messenger Dalam Tinjauan Manfaat Dan Adab. Wahana Akademika: Jurnal Studi Islam Dan Sosial, 3(1), 51. https://doi.org/10.21580/wa.v3i1.872

Kamila, P. H. (2019). Pengaruh Pemanfaatan Media Sosial Whatsapp terhadap Motivasi Belajar Bahasa Indonesia di SMP Islam Al Wahab Jakarta. UIN Syarif Hidayatullah.

Kuntarto, E. (2017). Keefektifan Model Pembelajaran Daring Dalam Perkuliahan Bahasa Indonesia di Perguruan tinggi. Journal Indonesian Language Education and Literature, 3(1), 53-65.

Kuo, Y. C., Walker, A. E., Schroder, K. E. E., \& Belland, B. R. (2014). Interaction, Internet selfefficacy, and self-regulated learning as predictors of student satisfaction in online education courses. Internet and Higher Education, 20, 35-50. https://doi.org/10.1016/j.iheduc.2013.10.001

Oknisih, N., Wahyuningsih, Y., \& Suryoto. (2019). Penggunaan Aplen (aplikasi online ) sebagai upaya kemandirian belajar siswa. In Seminar Nasional Pendidikan Dasar (pp. 477-483).

Oktavian, R., \& Aldya, R. F. (2020). Efektivitas Pembelajaran Daring Terintegrasi di Era Pendidikan 4.0. Didaktis: Jurnal Pendidikan Dan Ilmu Pengetahuan, 20(2), 129-135. https://doi.org/10.30651/didaktis.v20i2.4763

Prajana, A. (2017). Pemanfaatan Aplikasi Whatsapp Untuk Media Pembelajaran Dalam Lingkungan 
Uin Ar-Raniry Banda Aceh. Cyberspace: Jurnal Pendidikan Teknologi Informasi, 1(2), 122. https://doi.org/10.22373/cs.v1i2.1980

Pranajaya, \& Wicaksono, H. (2018). PEMANFAATAN APLIKASI WHATSAPP (WA) DI KALANGAN PELAJAR: STUDI KASUS DI MTS AL MUDDATSIRIYAH DAN MTS JAKARTA PUSAT. Orbith: Majalah Ilmiah Pengembangan Rekayasa Dan Sosial, 14(1), 59-67.

So, S. (2016). Mobile instant messaging support for teaching and learning in higher education. Internet and Higher Education, 31, 32-42. https://doi.org/10.1016/j.iheduc.2016.06.001

Suryadi, E., Ginanjar, M. H., \& Priyatna, M. (2018). PENGGUNAAN SOSIAL MEDIA WHATSAPP PENGARUHNYA TERHADAP DISIPLIN BELAJAR PESERTA DIDIK PADA MATA PELAJARAN PENDIDIKAN AGAMA ISLAM (Studi Kasus Di SMK Analis Kimia YKPI Bogor). Edukasi Islami: Jurnal Pendidikan Islam, 7(1), 1. https://doi.org/10.30868/ei.v7i01.211

Trisnani. (2017). Pemanfaatan Whatsapp Sebagai Media Komunikasi Dan Kepuasan Dalam Penyampaian Pesan Dikalangan Tokoh Masyarakat. Jurnal Komunika: Jurnal Komunikasi, Media Dan Informatika, 6(3). https://doi.org/10.31504/komunika.v6i3.1227 